\title{
Lung injury after cigarette smoking is particle related
}

This article was published in the following Dove Press journal:

International Journal of COPD

9 March 201I

Number of times this article has been viewed

\section{Rahul G Sangani \\ Andrew J Ghio}

Environmental Public Health Division, National Health and Environmental

Effects Research Laboratory,

US Environmental Protection

Agency, Chapel Hill, NC, USA
Correspondence: Andrew J Ghio

Human Studies Facility,

US Environmental Protection

Agency, Campus Box 7315,

104 Mason Farm Road, Chapel Hill,

NC 27599-73I5, USA

Tel +19199660670

Fax + I 919966 4767

Email ghio.andy@epa.gov
Abstract: The specific component responsible and the mechanistic pathway for increased human morbidity and mortality after cigarette smoking are yet to be delineated. We propose that 1) injury and disease following cigarette smoking are associated with exposure to and retention of particles produced during smoking and 2) the biological effects of particles associated with cigarette smoking share a single mechanism of injury with all particles. Smoking one cigarette exposes the human respiratory tract to between 15,000 and $40,000 \mu \mathrm{g}$ particulate matter; this is a carbonaceous product of an incomplete combustion. There are numerous human exposures to other particles, and these vary widely in composition, absolute magnitude, and size of the particle. Individuals exposed to all these particles share a common clinical presentation with a loss of pulmonary function, increased bronchial hyperresponsiveness, pathologic changes of emphysema and fibrosis, and comorbidities, including cardiovascular disease, cerebrovascular disease, peripheral vascular disease, and cancers. Mechanistically, all particle exposures produce an oxidative stress, which is associated with a series of reactions, including an activation of kinase cascades and transcription factors, release of inflammatory mediators, and apoptosis. If disease associated with cigarette smoking is recognized to be particle related, then certain aspects of the clinical presentation can be predicted; this would include worsening of pulmonary function and progression of pathological changes and comorbidity (eg, emphysema and carcinogenesis) after smoking cessation since the particle is retained in the lung and the exposure continues.

Keywords: particulate matter, smoking, oxidants, oxidative stress, air pollution

\section{Introduction}

Smoking is one of the ten greatest contributors to global death and disease ${ }^{1}$ and is the single most important risk factor for chronic obstructive pulmonary disease (COPD), cardiovascular disease, cerebrovascular disease, peripheral vascular disease, and numerous cancers in the United States. ${ }^{2}$ The specific component responsible and the mechanistic pathway for increased human morbidity and mortality after cigarette smoking are yet to be delineated. Cigarette smoking is a particle-related exposure. While obvious disparities exist between cigarette smoking and exposures to other particles, there are many similarities in the physiologic changes, pathology, and comorbidities. We propose that 1) injury and disease following cigarette smoking are associated with exposure and retention of particles produced during smoking and 2) the biological effects of particles associated with cigarette smoking share a single mechanism of injury with all particles.

\section{Human exposures to particles}

In a burning cigarette, temperatures in the combustion zone $\left(800^{\circ} \mathrm{C}-950^{\circ} \mathrm{C}\right)$ result in a complete pyrolysis of tobacco. ${ }^{3}$ Immediately downstream, a rapid drop in temperature 
(to $200^{\circ} \mathrm{C}-600^{\circ} \mathrm{C}$ ) and a lack of oxygen allow for incomplete combustion of tobacco. Subsequently, a complex aerosol is generated during smoking, which includes condensed liquid droplets (the particulate fraction or tar) suspended in a mixture of volatile and semivolatile compounds and combustion gases (the gas fraction). Smoking one cigarette exposes the human respiratory tract to between 15,000 and 40,000 $\mu \mathrm{g}$ particulate matter (PM). ${ }^{4}$ The composition of cigarette smoke PM is comparable to that of other particles generated through an incomplete combustion of carbonaceous material, and this includes a heterogeneous, amorphous, organic material. ${ }^{5-7}$

Human exposures to other particles vary in composition, absolute magnitude, and size of the particle (Table 1). After cigarette smoking, the burning of biomass (defined as some combination of wood, charcoal, agricultural residues, and animal dung) is likely to be the PM source of greatest significance internationally. More than 2 billion people in the world use biomass as their main source of energy for domestic heating and cooking, and $80 \%$ of total global exposure to PM occurs indoors in developing nations.

\section{Particle-related lung injury}

Individuals exposed to all these different particles share a common clinical presentation. Depending on the composition, magnitude, and duration of the particle exposure, there can be 1) loss of pulmonary function, 2) increased bronchial hyperresponsiveness, 3) pathological alterations of emphysema and fibrosis, 4) hemorheological changes, and 5) comorbidities, including cardiovascular disease, cerebrovascular disease, peripheral vascular disease, and cancers.

\section{Loss of pulmonary function}

Smoking cigarettes decreases all indices of lung function but particularly affects flows. ${ }^{8}$ On an average, moderate-to-heavy male smokers have a $15 \mathrm{~mL} /$ year larger decline in forced expiratory volume in $1 \mathrm{sec}$ relative to nonsmokers. ${ }^{9}$ The greater the number of cigarettes smoked (ie, pack years), the higher the rate of decline in lung function. ${ }^{9}$ The extreme loss of function after cigarette smoking can result in COPD, a major cause of morbidity and mortality throughout the world. COPD, a disease state characterized by airflow limitation that is not fully reversible, is currently the fourth leading cause of death in the world, and further increase in the prevalence and mortality of the disease is predicted in the coming decades. Internationally, the prevalence of COPD is highest in countries where cigarette smoking is common. ${ }^{10}$

Other particle exposures are similarly associated with loss in pulmonary function and COPD. Environmental tobacco smoke (ETS), ${ }^{11-13}$ woodstove emissions, ${ }^{14}$ use of gas stoves, burning of biomass other than wood, ${ }^{15-19}$ and air pollution particles ${ }^{20}$ decrease indices of pulmonary function. COPD has been observed among nonsmoking individuals exposed to both open fires/burning of biomass ${ }^{21,22}$ and occupational dusts, including coal and mineral oxide particles. $^{23}$

\section{Bronchial hyperreactivity}

Cigarette smoking ${ }^{24,25}$ and ETS exposure ${ }^{26,27}$ elevate bronchial hyperresponsiveness. There is a dose-dependent relationship between the number of cigarettes smoked and the degree of hyperresponsiveness. ${ }^{28}$ Particles other than those in cigarette smoke similarly affect bronchial hyperresponsiveness. Diesel exposure has been associated with

Table I Particle-related exposures associated with human lung injury

\begin{tabular}{|c|c|c|c|}
\hline Particle source & Composition of particle & Magnitude of exposure & Particle size \\
\hline Cigarette smoking & Carbonaceous combustion product & 15,000-40,000 $\mu \mathrm{g} /$ cigarette & Fine and ultrafine \\
\hline $\begin{array}{l}\text { Environmental tobacco } \\
\text { smoke }\end{array}$ & Carbonaceous combustion product & $\leq 1000 \mu \mathrm{g} / \mathrm{m}^{3}$ & Fine and ultrafine \\
\hline Forest fires ${ }^{140}$ & Carbonaceous combustion product & $\leq 1000 \mu \mathrm{g} / \mathrm{m}^{3}$ but variable & Fine and ultrafine \\
\hline Wood-burning stove $\left.\right|^{|4|-\mid 43}$ & Carbonaceous combustion product & $\leq 1200 \mu \mathrm{g} / \mathrm{m}^{3}$ & Fine and ultrafine \\
\hline Gas stove ${ }^{144,145}$ & Carbonaceous combustion product & $\leq 1380 \mu \mathrm{g} / \mathrm{m}^{3}$ & Fine and ultrafine \\
\hline Diesel exhaust ${ }^{146,147}$ & Carbonaceous combustion product & $\begin{array}{l}\leq 10 \mu \mathrm{g} / \mathrm{m}^{3} \text { in ambient air } \\
<1000 \mu \mathrm{g} / \mathrm{m}^{3} \text { in mines }\end{array}$ & Ultrafine \\
\hline Burning of biomass ${ }^{145,148-150}$ & Carbonaceous combustion product & $\leq 10,000 \mu \mathrm{g} / \mathrm{m}^{3}$ but variable & Coarse, fine, and ultrafine \\
\hline Air pollution ${ }^{151}$ & Variable & $\begin{array}{l}\leq 50 \mu \mathrm{g} / \mathrm{m}^{3} \text { nationally } \\
\leq 500 \mu \mathrm{g} / \mathrm{m}^{3} \text { internationally }\end{array}$ & Coarse, fine, and ultrafine \\
\hline Coal mining & Carbonaceous & $\leq 2000 \mu \mathrm{g} / \mathrm{m}^{3}$ nationally & Coarse and fine \\
\hline Mining of minerals & Inorganic (eg, silica and silicates) & $\begin{array}{l}\leq 1000 \mu \mathrm{g} / \mathrm{m}^{3} \text { for silica } \\
\leq 5000 \mu \mathrm{g} / \mathrm{m}^{3} \text { for nuisance dust }\end{array}$ & Coarse and fine \\
\hline
\end{tabular}


comparable changes in bronchial hyperresponsiveness. ${ }^{29}$ The response to methacholine also increases following exposure of firefighters. ${ }^{30-32}$ Occupational exposure to dust can increase airway reactivity, including both coal dust $\mathrm{t}^{24,33}$ and mineral oxide. ${ }^{34}$ This relationship between particle exposure and bronchial responsiveness is widely recognized, and a challenge inhalation with particles has been proposed as an alternative to methacholine testing. ${ }^{35,36}$

\section{Lung histopathology}

Cigarette smoking has been associated with an acute influx of neutrophils into the lower respiratory tract. ${ }^{37}$ This is comparable to other particle-associated injuries, including exposures to ambient air pollution particles and diesel exhaust. $^{38,39}$

The two chronic pathologic processes noted on microscopic inspection of the lungs from individuals exposed to particles are emphysema and fibrosis. Emphysema is most frequently caused by cigarette smoking, but is also observed after other particle exposures, including burning of biomass, ${ }^{40}$ mineral oxide, ${ }^{23,41,42}$ and coal dust. ${ }^{43-47}$ Histologically, emphysema, following all these exposures, including cigarette smoking, occurs immediately adjacent to the retained particle. ${ }^{48-51}$ In one animal study, the emphysema severity was dependent on the concentration of cigarette smoke total PM. ${ }^{52}$ Mucous cell hyperplasia, hypertrophy, and inflammatory cell infiltrates were present in the epithelium of large airways of cigarette smoke-exposed mouse lungs. Further, allowing the mice to recover from cigarette smoke exposure was not associated with reversal of emphysema, and cigarette smoke-induced pulmonary inflammation also persisted.

Fibrosis can also be observed following exposures to numerous different particle exposures. Increased collagen is frequently observed in the lungs of cigarette smokers, ${ }^{53-55}$ and irregular opacities reflecting this fibrosis can be observed on their chest X-rays comparable to those in pneumoconioses. ${ }^{23,56-58}$ Collagen deposition and fibrosis in the human lung have been described following exposure to ambient air pollution particles,${ }^{59}$ environmental exposure to crustal particles (eg, windstorms), ${ }^{60,61}$ and inhalation of emission source particles. ${ }^{62}$ This fibrogenic property of particles is exploited therapeutically with the instillation of gram quantities of a mineral oxide (ie, talc) particle into the pleural space to provide sclerosis. ${ }^{63}$

\section{Hemorheological changes}

Cigarette smoking leads to a rise in hematocrit, increased total white cell count, and modified leukocyte function.
Elevations in the plasma concentrations of fibrinogen are also associated with smoking; ${ }^{64,65}$ a dose-response relationship between smoking and the plasma fibrinogen level has been described.$^{66}$ Following smoking cessation, plasma fibrinogen will drop immediately but takes 5 years to return to normal. ${ }^{67}$ Abnormalities in platelet function can similarly occur with smoking with an increase in platelet aggregation occurring as rapidly as $10 \mathrm{~min}$ after smoking a cigarette. ${ }^{68,69}$

Other particle exposures elicit comparable changes in blood components. ETS exposure can be associated with platelet aggregation. ${ }^{70}$ Ambient air pollution particles effect several changes in the peripheral blood, including decreases in red cell number, ${ }^{71}$ elevations in white blood cell counts, ${ }^{71}$ and increases in C-reactive protein, ${ }^{71}$ fibrinogen, ${ }^{38,71,72}$ and blood viscosity; ${ }^{71,73}$ the last two potentially contribute to the association of ambient PM with thrombotic events. ${ }^{74}$ Other particles have comparable effects on hemorheologic indices. ${ }^{75,76}$

\section{Comorbidities}

Cigarette smoking is the major risk factor in many industrialized societies for cardiovascular disease and increases the prevalence of coronary artery disease, ${ }^{77,78}$ cerebrovascular disease, ${ }^{79}$ and peripheral vascular disease ${ }^{80}$ Convincing evidence also links ETS exposure to both cardiac morbidity and mortality and peripheral vascular disease. ${ }^{81}$ Forest firefighting ${ }^{82}$ and diesel exhaust ${ }^{83}$ similarly elevate the rate of cardiovascular disease. The inhalation of ambient air pollution PM can increase the incidence of myocardial infarction, ${ }^{84}$ hospital admission for cardiovascular diseases, ${ }^{85}$ and the rate of arrhythmias. ${ }^{86}$ Finally, exposures to mineral oxide and coal dust can be associated with an increased risk for cardiovascular disease. ${ }^{87,88}$

There are elevations in the incidence of cancer with either cigarette smoking ${ }^{89}$ or exposure to ETS. ${ }^{90,91}$ There is also concern for an induction of neoplasms by other particleassociated injuries, including that induced by diesel exhaust, ${ }^{92}$ forest fire fighting, ${ }^{93}$ burning of biomass other than wood, ${ }^{94}$ the use of wood-burning stoves, ${ }^{95}$ and occupational exposures to silica. ${ }^{96}$ Recent investigation has similarly suggested a carcinogenicity of ambient air pollution particles. ${ }^{97}$

\section{Mechanism of injury following particle exposures}

Shared characteristics of the physiologic response, pathology, and comorbidities between PM included in cigarette smoke and other particles suggest a common mechanism of biological effect. All particle exposures produce an oxidative stress. 
A generation of reactive oxygen species results either directly from some component of the particle supporting an inappropriate electron transfer or from an interaction of the PM with cell proteins (eg, electron transport complexes in the mitochondria). Oxidative stress is accepted as the initial step in the biological effect after cigarette smoking ${ }^{98}$ and all other particle exposures. ${ }^{99}$

Oxidants generated by particle exposures can cause sequential changes culminating in tissue injury (Figure 1). Among the early cell targets of oxidative stress are kinase cascades. Mitogen-activated protein (MAP) kinases (p38 MAP kinase family, the extracellular signal-regulated kinase (ERK) family, and the c-Jun $\mathrm{NH}_{2}$-terminal kinase (JNK) family) are widely expressed serine-threonine kinases which mediate regulatory signals in the cell. The activation of specific MAP kinase signaling cascades is required for induction of various cellular responses, including phosphorylation of transcription factors (eg, NF-E2-related factor 2 (Nrf2), nuclear transcription factor-kappaB (NF-kB), and activator protein-1 (AP-1)) and transcriptional regulation, nuclear chromatin remodeling and gene induction, cytokine production, as well as regulation of apoptosis and cell-cycle progression. ${ }^{100}$ Exposure to cigarette smoke leads to activation of MAP kinases and pro-inflammatory transcription factors (Nrf2, NF-kB, and AP-1), and this is considered to be a key mechanistic event leading to cell differentiation, release of inflammatory mediators, and inflammatory

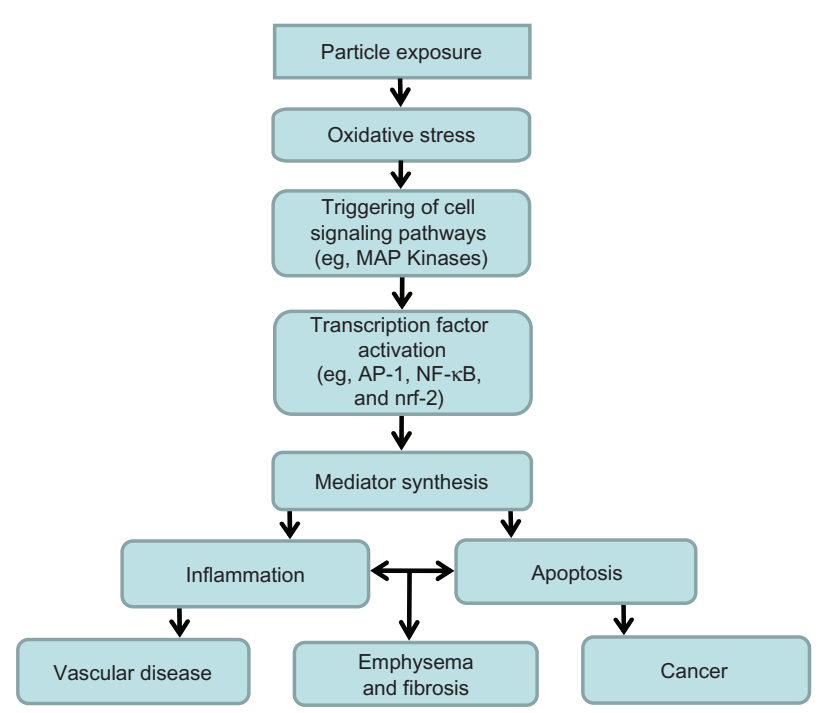

Figure I Mechanism of biological effect following particle exposure. Particles effect an oxidative stress, which prompts a series of reactions by the host, including activation of cell signaling pathways and transcription factors and inflammatory mediator release. This culminates in inflammation and apoptosis which, if prolonged or misregulated, can produce emphysema, fibrosis, vascular disease, and cancer. Abbreviations: MAP, mitogen-activated protein; AP-I, activator protein-I; NF-kB, nuclear transcription factor-kappaB; Nrf2, NF-E2-related factor 2. injury in the lungs. ${ }^{101-107}$ Regarding one transcription factor, macrophage exposure to cigarette smoke induced nuclear accumulation of Nrf2 and activated the transcription of Nrf2 target genes. ${ }^{108}$ This suggests that Nrf2 in macrophages may participate in the human response to cigarette smoke exposure. Basal Nrf2 mRNA levels and Nrf2 target gene expressions were significantly lower in alveolar macrophages obtained from 1) older current smokers relative to and from lifelong nonsmokers and 2) patients with COPD relative to nonsmokers and former smokers without COPD. The same cascade of reactions (Figure 1) appears to also participate in cell apoptosis after cigarette smoke exposure. ${ }^{109-114}$

The pathway of inflammation and apoptosis following exposure to other particles is indistinguishable from that after cigarette smoke exposure (Figure 1). Numerous PM exposures activate the same kinases and pro-inflammatory transcription factors observed with cigarette smoke. ${ }^{115-118}$ Comparable to cigarette smoke, the same particles subsequently affect a release of inflammatory and apoptotic mediators. ${ }^{119-124}$

Activation of kinase cascades and transcription factors following particle exposure can also effect an inflammatory and apoptotic response in extrapulmonary sites. Mainstream cigarette smoke exposure is associated with activation of p38 and ERK1/2 MAP kinases. ${ }^{125}$ Ambient air pollution particles similarly induce reactive oxygen species generation in human endothelial cells, resulting in cell barrier disruption via p38 MAP kinase-dependent pathways. ${ }^{126,127}$ These findings support one common pathway for biological effect of all particles in all tissues.

\section{Conclusions}

Particle-related biological effects continue to be defined. Investigation has demonstrated comparable effects of cigarette smoke and other particle-related exposures. A shared mechanism of biological effect between cigarette smoking and other particle exposures would further understanding of human disease. If disease associated with cigarette smoking is recognized to be particle related, then certain aspects of the clinical presentation can be predicted. For example, worsening of pulmonary function and progression of pathological changes after smoking cessation is predicted since the particle continues to be sequestered in the lung, and biological effect corresponds to such persistence. ${ }^{128-130}$ Finally, a shared pathway of biological effect predicts that genetic predisposition to one particle-related injury may also influence another (eg, polymorphisms in glutathione transferase will function as a risk factor in injury after cigarette smoking and exposure 
to air pollution particles). ${ }^{131,132}$ Those genetic factors which are demonstrated to participate in lung injury after either cigarette smoking or other specific disease following particle exposure should be examined for a contribution in any of the particle-related diseases. ${ }^{133-136}$

\section{Disclaimer}

This report has been reviewed by the National Health and Environmental Effects Research Laboratory, United States Environmental Protection Agency, and approved for publication. Approval does not signify that the contents necessarily reflect the views and policies of the agency nor does mention of trade names or commercial products constitute endorsement or recommendation for use.

\section{Disclosure}

The authors report no conflicts of interest in this work.

\section{References}

1. The World Health Report 2002: Reducing Risks, Promoting Healthy Life. Geneva (Switzerland): World Health Organization; 2002.

2. Sherman CB. Health effects of cigarette smoking. Clin Chest Med. 1991;12(4):643-658.

3. Johnson WR. Pyrogenesis and physiochemical nature of tobacco smoke. In: Tobacco Smoke: Its Formation and Composition. Kingsport (TN): Tennessee Eastman;1977:1-26.

4. Environmental Tobacco Smoke: Measuring Exposures and Assessing Health Effects. Washington (DC): National Research Council, National Academy Press; 1986.

5. Baker RR. Smoke chemistry. In: Davis DL, Nielsen MT, editors. Tobacco-Production, Chemistry and Technology. Oxford (UK) Blackwell Science. 2000:398-439.

6. Ghio AJ, Stonehuerner J, Pritchard RJ, et al. Humic-like substances in air pollution particulates correlate with concentrations of transition metals and oxidant generation. Inh Toxicol. 1996;8(5):479-494.

7. Ghio AJ, Stonehuerner J, Quigley DR. Humic-like substances in cigarette smoke condensate and lung tissue of smokers. Am J Physiol. 1994;266(4 Pt 1):L382-L388.

8. Ashley F, Kannel WB, Sorlie PD, Masson R. Pulmonary function: relation to aging, cigarette habit, and mortality. Ann Intern Med. 1975; 82(6):739-745.

9. Kerstjens HA, Rijcken B, Schouten JP, Postma DS. Decline of FEV1 by age and smoking status: facts, figures, and fallacies. Thorax. 1997; 52(9):820-827.

10. Pauwels RA, Buist AS, Calverley PM, Jenkins CR, Hurd SS; GOLD Scientific Committee. Global strategy for the diagnosis, management, and prevention of chronic obstructive pulmonary disease. NHLBI/ WHO Global Initiative for Chronic Obstructive Lung Disease (GOLD) Workshop summary. Am J Respir Crit Care Med. 2001;163(5): 1256-1276.

11. Hamosh P, Taveira da Silva AM. The effect on expiratory flow rates of smoking three cigarettes in rapid succession. Chest. 1977;72(5): 610-613.

12. Sockrider M. The respiratory effects of passive tobacco smoking. Curr Opin Pulm Med. 1996;2(2):129-133.

13. Mannino DM, Moorman JE, Kingsley B, Rose D, Repace J. Health effects related to environmental tobacco smoke exposure in children in the United States: data from the Third National Health and Nutrition Examination Survey. Arch Pediatr Adolesc Med. 2001;155(1): $36-41$.
14. Dennis RJ, Maldonado D, Norman S, Baena E, Martinez G. Woodsmoke exposure and risk for obstructive airways disease among women. Chest. 1996;109(1):115-119.

15. Malik SK. Exposure to domestic cooking fuels and chronic bronchitis. Indian J Chest Dis Allied Sci. 1985;27(3):171-174.

16. Jindal SK. A field study on follow up at 10 years of prevalence of chronic obstructive pulmonary disease and peak expiratory flow rate. Indian J Med Res. 1993;98:20-26.

17. Behera D, Jindal SK, Malhotra HS. Ventilatory function in nonsmoking rural Indian women using different cooking fuels. Respiration. 1994; 61(2):89-92.

18. Perez-Padilla R, Regalado J, Vedal S, et al. Exposure to biomass smoke and chronic airway disease in Mexican women. A case-control study. Am J Respir Crit Care Med. 1996;154(3 Pt 1):701-706.

19. Behera D, Sood P, Singh S. Passive smoking, domestic fuels and lung function in north Indian children. Indian J Chest Dis Allied Sci. 1998; 40(2):89-98.

20. Gauderman WJ, Avol E, Gilliland F, et al. The effect of air pollution on lung development from 10 to 18 years of age. $N$ Engl J Med. 2004; 351(11):1057-1067.

21. Døssing M, Khan J, al-Rabiah F. Risk factors for chronic obstructive lung disease in Saudi Arabia. Respir Med. 1994;88(7):519-522.

22. Jarvis D, Chinn S, Luczynska C, Burney P. Association of respiratory symptoms and lung function in young adults with use of domestic gas appliances. Lancet. 1996;347(8999):426-431.

23. Cowie RL, Hay M, Thomas RG. Association of silicosis, lung dysfunction, and emphysema in gold miners. Thorax. 1993;48(7):746-749.

24. Hodgins P, Henneberger PK, Wang ML, Petsonk EL. Bronchial responsiveness and five-year FEV1 decline: a study in miners and nonminers. Am J Respir Crit Care Med. 1998;157(5 Pt 1):1390-1396.

25. Jensen EJ, Dahl R, Steffensen F. Bronchial reactivity to cigarette smoke; relation to lung function, respiratory symptoms, serumimmunoglobulin E and blood eosinophil and leukocyte counts. Respir Med. 2000;94(2):119-127.

26. Menon P, Rando RJ, Stankus RP, Salvaggio JE, Lehrer SB. Passive cigarette smoke-challenge studies: increase in bronchial hyperreactivity. J Allergy Clin Immunol. 1992;89(2):560-566.

27. Nowak D, Jörres R, Schmidt A, Magnussen H. Effect of 3 hours' passive smoke exposure in the evening on airway tone and responsiveness until next morning. Int Arch Occup Environ Health. 1997;69(2): $125-133$.

28. Gerrard JW, Cockcroft DW, Mink JT, Cotton DJ, Poonawala R, Dosman JA. Increased nonspecific bronchial reactivity in cigarette smokers with normal lung function. Am Rev Respir Dis. 1980;122(4): $577-581$.

29. Wade JF 3rd, Newman LS. Diesel asthma. Reactive airways disease following overexposure to locomotive exhaust. J Occup Med. 1993; 35(2):149-154.

30. Sheppard D, Distefano S, Morse L, Becker C. Acute effects of routine firefighting on lung function. Am J Ind Med. 1986;9(4):333-340.

31. Sherman CB, Barnhart S, Miller MF, et al. Firefighting acutely increases airway responsiveness. Am Rev Respir Dis. 1989;140(1):185-190.

32. Liu D, Tager IB, Balmes JR, Harrison RJ. The effect of smoke inhalation on lung function and airway responsiveness in wildland fire fighters. Am Rev Respir Dis. 1992;146(6):1469-1473.

33. Hudgel DW, Roe R. Nonspecific airway hyperreactivity in nonsmoking bituminous coal miners demonstrated by quantitative methacholine inhalation challenge. J Lab Clin Med. 1988;111(6):684-691.

34. Leuenberger P, Schindler C, Schwartz J, et al. Occupational exposure to inhalative irritants and methacholine responsiveness. Scand J Work Environ Health. 2000;26(2):146-152.

35. Wiles FJ, Johnston JR, Le Roux AF, Churchill AR. Acute exposure to gold mine dust - a bronchial challenge test? Ann Occup Hyg. 1982; 26(1-4):663-675.

36. Cloutier Y, Lagier F, Cartier A, Malo JL. Validation of an exposure system to particles for the diagnosis of occupational asthma. Chest. 1992;102(2):402-407. 
37. Burns DM. Cigarettes and cigarette smoking. Clin Chest Med. 1991; 12(4):631-642.

38. Ghio AJ, Kim C, Devlin RB. Concentrated ambient air particles induce mild pulmonary inflammation in healthy human volunteers. Am J Respir Crit Care Med. 2000;162(3 Pt 1):981-988.

39. Rudell B, Blomberg A, Helleday R, et al. Bronchoalveolar inflammation after exposure to diesel exhaust: comparison between unfiltered and particle trap filtered exhaust. Occup Environ Med. 1999;56(8): 527-534.

40. Ozbay B, Uzun K, Arslan H, Zehir I. Functional and radiological impairment in women highly exposed to indoor biomass fuels. Respirology. 2001;6(3):255-258.

41. Bégin R, Filion R, Ostiguy G. Emphysema in silica- and asbestosexposed workers seeking compensation. A CT scan study. Chest. 1995;108(3):647-655.

42. Wang X, Yano E. Pulmonary dysfunction in silica-exposed workers: a relationship to radiographic signs of silicosis and emphysema. Am J Ind Med. 1999;36(2):299-306.

43. Ryder R, Lyons JP, Campbell H, Gough J. Emphysema in coal workers' pneumoconiosis. Br Med J. 1970;3(5721):481-487.

44. Leigh J, Outhred KG, McKenzie HI, Glick M, Wiles AN. Quantified pathology of emphysema, pneumoconiosis, and chronic bronchitis in coal workers. Br J Ind Med. 1983;40(3):258-263.

45. Lyons JP, Campbell H. Relation between progressive massive fibrosis, emphysema, and pulmonary dysfunction in coalworkers' pneumoconiosis. Br J Ind Med. 1981;38(2):125-129.

46. Ruckley VA, Gauld SJ, Chapman JS, et al. Emphysema and dust exposure in a group of coal workers. Am Rev Respir Dis. 1984;129(4): 528-532.

47. Leigh J, Driscoll TR, Cole BD, Beck RW, Hull BP, Yang J. Quantitative relation between emphysema and lung mineral content in coalworkers. Occup Environ Med. 1994;51(6):400-407.

48. Ghio AJ, Hilborn ED, Stonehuerner JG, et al. Particulate matter in cigarette smoke alters iron homeostasis to produce a biological effect. Am J Respir Crit Care Med. 2008;178(11):1130-1138.

49. Churg A, Zay K, Li K. Mechanisms of mineral dust-induced emphysema. Environ Health Perspect. 1997;105 Suppl 5:1215-1218.

50. Mitchell RS, Vincent TN, Filley GF. Cigarette smoking, chronic bronchitis, and emphysema. JAMA. 1964;188:12-16.

51. Pratt PC, Jutabha P, Klugh GA. The relationship between pigment deposits and lesions in normal and centrilobular emphysematous lungs. Am Rev Respir Dis. 1963;87:245-256.

52. March TH, Wilder JA, Esparza DC, et al. Modulators of cigarette smoke-induced pulmonary emphysema in A/J mice. Toxicol Sci. 2006; 92(2):545-559.

53. Adesina AM, Vallyathan V, McQuillen EN, Weaver SO, Craighead JE. Bronchiolar inflammation and fibrosis associated with smoking. A morphologic cross-sectional population analysis. Am Rev Respir Dis. 1991;143(1):144-149.

54. Lang MR, Fiaux GW, Gillooly M, Stewart JA, Hulmes DJ, Lamb D. Collagen content of alveolar wall tissue in emphysematous and non-emphysematous lungs. Thorax. 1994;49(4):319-326.

55. Katzenstein AL, Mukhopadhyay S, Zanardi C, Dexter E. Clinically occult interstitial fibrosis in smokers: classification and significance of a surprisingly common finding in lobectomy specimens. Hum Pathol. 2010;41(3):316-325.

56. Weiss W. Cigarette smoking and diffuse pulmonary fibrosis. Am Rev Respir Dis. 1969;99(1):67-72.

57. Wiggins J, Strickland B, Turner-Warwick M. Combined cryptogenic fibrosing alveolitis and emphysema: the value of high resolution computed tomography in assessment. Respir Med. 1990;84(5):365-369.

58. Dick JA, Morgan WK, Muir DF, Reger RB, Sargent N. The significance of irregular opacities on the chest roentgenogram. Chest. 1992;102(1):251-260.

59. Pinkerton KE, Green FH, Saiki C, et al. Distribution of particulate matter and tissue remodeling in the human lung. Environ Health Perspect. 2000;108(11):1063-1069.
60. Bar-Ziv J, Goldberg GM. Simple siliceous pneumoconiosis in Negev Bedouins. Arch Environ Health. 1974;29(3):121-126.

61. Saiyed HN, Sharma YK, Sadhu HG, et al. Non-occupational pneumoconiosis at high altitude villages in central Ladakh. $\mathrm{Br} J$ Ind Med. 1991;48(12):825-829.

62. Golden EB, Warnock ML, Hulett LD Jr, Churg AM. Fly ash lung: a new pneumoconiosis? Am Rev Respir Dis. 1982;125(1):108-112.

63. Rodriguez-Panadero F, Segado A, Martin Juan J, Ayerbe R, Torres Garcia I, Castillo J. Failure of talc pleurodesis is associated with increased pleural fibrinolysis. Am J Respir Crit Care Med. 1995;151 (3 Pt 1):785-790.

64. Ernst E. Haemorheological consequences of chronic cigarette smoking. J Cardiovasc Risk. 1995;2(5):435-439.

65. De Maat MP, Pietersma A, Kofflard M, Sluiter W, Kluft C. Association of plasma fibrinogen levels with coronary artery disease, smoking and inflammatory markers. Atherosclerosis. 1996;121(2):185-191.

66. Tauheed S, Shoaib S, Kamal A. Haemoglobin, haematocrit and plasma fibrinogen in cigarette smokers. J Pak Med Assoc. 1992;42(7): $162-163$.

67. Meade TW, Vickers MV, Thompson SG, Stirling Y, Haines AP, Miller GJ. Epidemiological characteristics of platelet aggregability. Br Med J (Clin Res Ed). 1985;290(6466):428-432.

68. Fusegawa Y, Handa S. Platelet aggregation induced by ADP or epinephrine is enhanced in habitual smokers. Thromb Res. 2000;97(5): 287-295.

69. Kutti J. Smoking, platelet reactivity and fibrinogen. In: Diana JN, editor. Tobacco Smoking and Atherosclerosis. New York: Plenum Press; 1990:129-134.

70. Davis JW, Shelton L, Watanabe IS, Arnold J. Passive smoking affects endothelium and platelets. Arch Intern Med. 1989;149(2): 386-389.

71. Seaton A, Soutar A, Crawford V, et al. Particulate air pollution and the blood. Thorax. 1999;54(11):1027-1032.

72. Pekkanen J, Brunner EJ, Anderson HR, Tiittanen P, Atkinson RW. Daily concentrations of air pollution and plasma fibrinogen in London. Occup Environ Med. 2000;57(12):818-822.

73. Peters A, Döring A, Wichmann HE, Koenig W. Increased plasma viscosity during an air pollution episode: a link to mortality? Lancet. 1997;349(9065):1582-1587.

74. Yarnell JW, Baker IA, Sweetnam PM, et al. Fibrinogen, viscosity, and white blood cell count are major risk factors for ischemic heart disease. The Caerphilly and Speedwell collaborative heart disease studies. Circulation. 1991;83(3):836-844.

75. Mattsby I, Rylander R. Clinical and immunological findings in workers exposed to sewage dust. J Occup Med. 1978;20(10): 690-692.

76. Fernandez Rego G, Ocio Achaerandio G, González Cuervo V, Rodríquez Menéndez C, Martínez Gonezález C, Alvarez Alvarez C. Presence of acute phase response in coal workers' pneumoconiosis. Br J Ind Med. 1991;48(3):193-195.

77. Villablanca AC, McDonald JM, Rutledge JC. Smoking and cardiovascular disease. Clin Chest Med. 2000;21(1):159-172.

78. Peters A, Perz S, Döring A, Stieber J, Koenig W, Wichmann HE. Increases in heart rate during an air pollution episode. Am J Epidemiol. 1999;150(10):1094-1098.

79. Hankey GJ. Smoking and risk of stroke. J Cardiovasc Risk. 1999;6(4): 207-211.

80. Criqui MH, Denenberg JO, Langer RD, Fronek A. The epidemiology of peripheral arterial disease: importance of identifying the population at risk. Vasc Med. 1997;2(3):221-226.

81. Kritz H, Schmid P, Sinzinger H. Passive smoking and cardiovascular risk. Arch Intern Med. 1995;155(18):1942-1948.

82. Melius JM. Cardiovascular disease among firefighters. Occup Med. 1995;10(4):821-827.

83. Edling C, Axelson O. Risk factors of coronary heart disease among personnel in a bus company. Int Arch Occup Environ Health. 1984; 54(2):181-183. 
84. Peters A, Dockery DW, Muller JE, Mittleman MA. Increased particulate air pollution and the triggering of myocardial infarction. Circulation. 2001;103(23):2810-2815.

85. Schwartz J. Air pollution and hospital admissions for heart disease in eight US counties. Epidemiology. 1999;10(1):17-22.

86. Peters A, Liu E, Verrier RL, et al. Air pollution and incidence of cardiac arrhythmia. Epidemiology. 2000;11(1):11-17.

87. Wyndham CH, Bezuidenhout BN, Greenacre MJ, Sluis-Cremer GK. Mortality of middle aged white South African gold miners. Br J Ind Med 1986;43(10):677-684.

88. Sjögren B. Occupational exposure to dust: inflammation and ischaemic heart disease. Occup Environ Med. 1997;54(7):466-469.

89. Murin S, Bilello KS, Matthay R. Other smoking-affected pulmonary diseases. Clin Chest Med. 2000;21(1):121-137, ix.

90. Trédaniel J, Boffetta P, Saracci R, Hirsch A. Exposure to environmental tobacco smoke and risk of lung cancer: the epidemiological evidence. Eur Respir J. 1994;7(10):1877-1888.

91. Reynolds P. Epidemiologic evidence for workplace ETS as a risk factor for lung cancer among nonsmokers: specific risk estimates. Environ Health Perspect. 1999;107 Suppl 6:865-872.

92. McClellan RO. Health effects of exposure to diesel exhaust particles. Annu Rev Pharmacol Toxicol. 1987;27:279-300.

93. Deschamps S, Momas I, Festy B. Mortality amongst Paris fire-fighters. Eur J Epidemiol. 1995;11(6):643-646.

94. Bruce N, Perez-Padilla R, Albalak R. Indoor air pollution in developing countries: a major environmental and public health challenge. Bull World Health Organ. 2000;78(9):1078-1092.

95. Hamada GS, Kowalski LP, Murata Y, Matsushita H, Matsuki H. Wood stove effects on indoor air quality in Brazilian homes: carcinogens, suspended particulate matter, and nitrogen dioxide analysis. Tokai J Exp Clin Med. 1992;17(3-4):145-153.

96. Holland LM. Crystalline silica and lung cancer: a review of recent experimental evidence. Regul Toxicol Pharmacol. 1990;12(3 Pt 1): 224-237.

97. Cohen AJ, Pope CA 3rd. Lung cancer and air pollution. Environ Health Perspect. 1995;103 Suppl 8:219-224.

98. Faux SP, Tai T, Thorne D, Xu Y, Breheny D, Gaca M. The role of oxidative stress in the biological responses of lung epithelial cells to cigarette smoke. Biomarkers. 2009;14 Suppl 1:90-96.

99. Tao F, Gonzalez-Flecha B, Kobzik L. Reactive oxygen species in pulmonary inflammation by ambient particulates. Free Radic Biol Med. 2003;35(4):327-340.

100. Platanias LC. Map kinase signaling pathways and hematologic malignancies. Blood. 2003;101(12):4667-4679.

101. Manna SK, Rangasamy T, Wise K, et al. Long term environmental tobacco smoke activates nuclear transcription factor-kappa B, activator protein-1, and stress responsive kinases in mouse brain. Biochem Pharmacol. 2006;71(11):1602-1609.

102. Zhong CY, Zhou YM, Douglas GC, Witschi H, Pinkerton KE. MAPK/ AP-1 signal pathway in tobacco smoke-induced cell proliferation and squamous metaplasia in the lungs of rats. Carcinogenesis. 2005;26(12):2187-2195.

103. Mossman BT, Lounsbury KM, Reddy SP. Oxidants and signaling by mitogen-activated protein kinases in lung epithelium. Am J Respir Cell Mol Biol. 2006;34(6):666-669.

104. Hoshino S, Yoshida M, Inoue K, et al. Cigarette smoke extract induces endothelial cell injury via JNK pathway. Biochem Biophys Res Commun. 2005;329(1):58-63.

105. Koch A, Giembycz M, Stirling RG, et al. Effect of smoking on MAP kinase-induced modulation of IL-8 in human alveolar macrophages. Eur Respir J. 2004;23(6):805-812.

106. Moretto N, Facchinetti F, Southworth T, Civelli M, Singh D, Patacchini R. alpha,beta-Unsaturated aldehydes contained in cigarette smoke elicit IL-8 release in pulmonary cells through mitogen-activated protein kinases. Am J Physiol Lung Cell Mol Physiol. 2009;296(5):L839-L848.

107. Hellermann GR, Nagy SB, Kong X, Lockey RF, Mohapatra SS Mechanism of cigarette smoke condensate-induced acute inflammatory response in human bronchial epithelial cells. Respir Res. 2002;3:22.
108. Suzuki M, Betsuyaku T, Ito Y, et al. Down-regulated NF-E2-related factor 2 in pulmonary macrophages of aged smokers and patients with chronic obstructive pulmonary disease. Am J Respir Cell Mol Biol. 2008;39(6):673-682

109. Demedts IK, Demoor T, Bracke KR, Joos GF, Brusselle GG. Role of apoptosis in the pathogenesis of COPD and pulmonary emphysema. Respir Res. 2006;7:53.

110. Rangasamy T, Misra V, Zhen L, Tankersley CG, Tuder RM, Biswal S. Cigarette smoke-induced emphysema in A/J mice is associated with pulmonary oxidative stress, apoptosis of lung cells, and global alterations in gene expression. Am J Physiol Lung Cell Mol Physiol. 2009;296(6):L888-L900.

111. Hu W, Xie J, Zhao J, Xu Y, Yang S, Ni W. Involvement of Bcl-2 family in apoptosis and signal pathways induced by cigarette smoke extract in the human airway smooth muscle cells. DNA Cell Biol. 2009;28(1): $13-22$.

112. Kuo WH, Chen JH, Lin HH, Chen BC, Hsu JD, Wang CJ. Induction of apoptosis in the lung tissue from rats exposed to cigarette smoke involves p38/JNK MAPK pathway. Chem Biol Interact. 2005; 155(1-2):31-42.

113. Wu CH, Lin $\mathrm{HH}$, Yan FP, Wu CH, Wang CJ. Immunohistochemical detection of apoptotic proteins, p53/Bax and JNK/FasL cascade, in the lung of rats exposed to cigarette smoke. Arch Toxicol. 2006;80(6): 328-336

114. Zhong CY, Zhou YM, Pinkerton KE. NF-kappaB inhibition is involved in tobacco smoke-induced apoptosis in the lungs of rats. Toxicol Appl Pharmacol. 2008;230(2):150-158.

115. Albrecht $\mathrm{C}$, Borm PJ, Adolf B, Timblin CR, Mossman BT. In vitro and in vivo activation of extracellular signal-regulated kinases by coal dusts and quartz silica. Toxicol Appl Pharmacol. 2002;184(1):37-45.

116. Reibman J, Hsu Y, Chen LC, et al. Size fractions of ambient particulate matter induce granulocyte macrophage colony-stimulating factor in human bronchial epithelial cells by mitogen-activated protein kinase pathways. Am J Respir Cell Mol Biol. 2002;27(4):455-462.

117. Kleinman MT, Araujo JA, Nel A, et al. Inhaled ultrafine particulate matter affects CNS inflammatory processes and may act via MAP kinase signaling pathways. Toxicol Lett. 2008;178(2):127-130.

118. Pourazar J, Mudway IS, Samet JM, et al. Diesel exhaust activates redox-sensitive transcription factors and kinases in human airways. Am J Physiol Lung Cell Mol Physiol. 2005;289(5):L724-L730.

119. Carter JD, Ghio AJ, Samet JM, Devlin RB. Cytokine production by human airway epithelial cells after exposure to an air pollution particle is metal-dependent. Toxicol Appl Pharmacol. 1997;146(2): $180-188$

120. Kamdar O, Le W, Zhang J, Ghio AJ, Rosen GD, Upadhyay D. Air pollution induces enhanced mitochondrial oxidative stress in cystic fibrosis airway epithelium. FEBS Lett. 2008;582(25-26): 3601-3606.

121. Lee TS, Liu YJ, Tang GJ, Yien HW, Wu YL, Kou YR. Wood smoke extract promotes both apoptosis and proliferation in rat alveolar epithelial type II cells: the role of oxidative stress and heme oxygenase-1. Crit Care Med. 2008;36(9):2597-2606.

122. Soberanes S, Panduri V, Mutlu GM, Ghio A, Bundinger GR, Kamp DW. p53 mediates particulate matter-induced alveolar epithelial cell mitochondria-regulated apoptosis. Am J Respir Crit Care Med. 2006; 174(11):1229-1238.

123. Upadhyay D, Panduri V, Ghio A, Kamp DW. Particulate matter induces alveolar epithelial cell DNA damage and apoptosis: role of free radicals and the mitochondria. Am J Respir Cell Mol Biol. 2003;29(2) $180-187$.

124. Zhang J, Ghio AJ, Chang W, Kamdar O, Rosen GD, Upadhyay D. Bim mediates mitochondria-regulated particulate matter-induced apoptosis in alveolar epithelial cells. FEBS Lett. 2007;581(22):4148-4152.

125. Gu L, Pandey V, Geenen DL, Chowdhury SA, Piano MR. Cigarette smoke-induced left ventricular remodelling is associated with activation of mitogen-activated protein kinases. Eur J Heart Fail. 2008;10(11):1057-1064. 
126. Wang T, Chiang ET, Moreno-Vinasco L, et al. Particulate matter disrupts human lung endothelial barrier integrity via ROS- and p38 MAPK-dependent pathways. Am J Respir Cell Mol Biol. 2010;42(4): 442-449.

127. Montiel-Dávalos A, Ibarra-Sánchez Mde J, Ventura-Gallegos JL, Alfaro-Moreno E, López-Marure R. Oxidative stress and apoptosis are induced in human endothelial cells exposed to urban particulate matter. Toxicol In Vitro. 2010;24(1):135-141.

128. Brozyna S, Ahern J, Hodge G, et al. Chemotactic mediators of Th1 T-cell trafficking in smokers and COPD patients. COPD. 2009;6(1): 4-16.

129. Hodge S, Hodge G, Holmes M, Reynolds PN. Increased airway epithelial and T-cell apoptosis in COPD remains despite smoking cessation. Eur Respir J. 2005;25(3):447-454.

130. Sethi S, Maloney J, Grove L, Wrona C, Berenson CS. Airway inflammation and bronchial bacterial colonization in chronic obstructive pulmonary disease. Am J Respir Crit Care Med. 2006;173(9):991-998.

131. Faramawy MM, Mohammed TO, Hossaini AM, Kashem RA, Abu Rahma RM. Genetic polymorphism of GSTT1 and GSTM1 and susceptibility to chronic obstructive pulmonary disease (COPD). J Crit Care. 2009;24(3):e7-e10.

132. Hong YC, Hwang SS, Kim JH, et al. Metals in particulate pollutants affect peak expiratory flow of schoolchildren. Environ Health Perspect. 2007;115(3):430-434.

133. Curjuric I, Imboden M, Schindler C, et al. HMOX1 and GST variants modify attenuation of FEF25-75\% decline due to PM10 reduction. Eur Respir J. 2010;35(3):505-514.

134. Hunninghake GM, Cho MH, Tesfaigzi Y, et al. MMP12, lung function, and COPD in high-risk populations. $N$ Engl J Med. 2009;361(27): 2599-2608.

135. Pabst S, Pizarro Touron C, Gillissen A, et al. ADAM33 gene polymorphisms in chronic obstructive pulmonary disease. Eur J Med Res. 2009;14 Suppl 4:182-186.

136. Ren C, Park SK, Vokonas PS, et al. Air pollution and homocysteine: more evidence that oxidative stress-related genes modify effects of particulate air pollution. Epidemiology. 2010;21(2):198-206.

137. Hammond SK, Leaderer BP. A diffusion monitor to measure exposure to passive smoking. Environ Sci Technol. 1987;21(5):494-497.

138. Husgafvel-Pursiainen K, Sorsa M, Møller M, Benestad C. Genotoxicity and polynuclear aromatic hydrocarbon analysis of environmental tobacco smoke samples from restaurants. Mutagenesis. 1986;1(4): 287-292.
139. Repace JL, Lowrey AH. Indoor air pollution, tobacco smoke, and public health. Science. 1980;208(4443):464-472.

140. Materna BL, Jones JR, Sutton PM, Rothman N, Harrison RJ. Occupational exposures in California wildland fire fighting. Am Ind Hyg Assoc J. 1992;53(1):69-76.

141. Larson TV, Koenig JQ. Wood smoke: emissions and noncancer respiratory effects. Annu Rev Public Health. 1994;15:133-156.

142. Ellegård A. Cooking fuel smoke and respiratory symptoms among women in low-income areas in Maputo. Environ Health Perspect. 1996;104(9):980-985.

143. Riojas-Rodríguez H, Romano-Riquer P, Santos-Burgoa C, Smith KR. Household firewood use and the health of children and women of Indian communities in Chiapas, Mexico. Int J Occup Environ Health. 2001;7(1):44-53.

144. Wong GW, Ko FW, Lau TS, et al. Temporal relationship between air pollution and hospital admissions for asthmatic children in Hong Kong. Clin Exp Allergy. 2001;31(4):565-569.

145. Naeher LP, Leaderer BP, Smith KR. Particulate matter and carbon monoxide in highland Guatemala: indoor and outdoor levels from traditional and improved wood stoves and gas stoves. Indoor Air. 2000;10(3):200-205.

146. Kinney PL, Aggarwal M, Northridge ME, Janssen NA, Shepard P. Airborne concentrations of PM(2.5) and diesel exhaust particles on Harlem sidewalks: a community-based pilot study. Environ Health Perspect. 2000;108(3):213-218.

147. Stayner L, Dankovic D, Smith R, Steenland K. Predicted lung cancer risk among miners exposed to diesel exhaust particles. Am J Ind Med. 1998;34(3):207-219.

148. Smith KR, Samet JM, Romieu I, Bruce N. Indoor air pollution in developing countries and acute lower respiratory infections in children. Thorax. 2000;55(6):518-532.

149. Smith KR. Fuel combustion, air pollution exposure, and health: the situation in developing countries. Annu Rev Energy Environ. 1993;18:529-566.

150. Ezzati M, Kammen D. Indoor air pollution from biomass combustion and acute respiratory infections in Kenya: an exposure-response study. Lancet. 2001;358(9282):619-624.

151. Air pollution in the world's megacities. A report from the UN Environment Programme and WHO. UN Environment Program and WHO Report: Environment; 1994:5-37.
International Journal of COPD

\section{Publish your work in this journal}

The International Journal of COPD is an international, peer-reviewed journal of therapeutics and pharmacology focusing on concise rapid reporting of clinical studies and reviews in COPD. Special focus is given to the pathophysiological processes underlying the disease, intervention programs, patient focused education, and self management protocols.

\section{Dovepress}

This journal is indexed on PubMed Central, MedLine and CAS. The manuscript management system is completely online and includes a very quick and fair peer-review system, which is all easy to use. Visit http://www.dovepress.com/testimonials.php to read real quotes from published authors. 